\title{
Oceano digital: imaginário marinho, tecnologia e identidade em Vilém Flusser ${ }^{1}$
}

Erick Felinto'

I - UERJ

Rio de Janeiro (RJ), Brasil

Resumo: Este texto explora o imaginário do mar e das criaturas marinhas no pensamento de Vilém Flusser, especialmente em seu singular livro Vampyroteuthis Infernalis. Nesse ensaio, o oceano constitui uma metáfora poética para pensar o universo das tecnologias digitais e dos fluxos técnicos da contemporaneidade. Almeja-se demonstrar que Vampyroteuthis Infernalis é não somente o trabalho mais original do autor, senão que dialoga, de modo quase profético e com profunda atualidade, com outros temas e pensadores contemporâneos no campo da teoria cultural. Segundo a leitura aqui sugerida, Vampyroteuthis Infernalis constituiria uma reflexão filosófica fundamental sobre o tema da identidade na relação com os aparatos tecnológicos e a cultura digital.

Palavras-Chave: Vilém Flusser; imaginário marinho; identidade; tecnologias digitais.

Abstract: Digital Ocean: marine imaginary, technology and identity in Vilém Flusser - This paper aims at investigating the imaginary of the sea and its marine creatures in Vilém Flusser's thought, specially in his most peculiar book, Vampyroteuthis Infernalis. This essay uses the ocean as a poetic metaphor to express the universe of digital technologies and its contemporary technical flows. The paper's goal is not only to show the radical originality of Flusser's book, but also to demonstrate its actuality and almost prophetic dimension by means of a dialogue with other contemporary themes and authors in the field of cultural theory. According to the reading suggested here, Vampyroteuthis Infernalis represents a fundamental philosophical reflection on the theme of identity in connection with technological devices and digital culture.

Keywords: Vilém Flusser; marine imaginary; identity; digital technologies.

1 Trabalho apresentado ao Grupo de Trabalho Imagens e Imaginários Midiáticos do XXVI Encontro Anual da Compós, Faculdade Cásper Líbero, São Paulo - SP, 06 a 09 de junho de 2017. 


\footnotetext{
" Jetant son encre vers les ciex, suçant le sang de ce qu'il aime et le trouvant délicieux, ce monstre inhumain, c'est moi-même " (Apollinaire, Le Poulpe)
}

\section{Sobre polvos e outros extraterrestres}

Em Arrival (2016), filme dirigido pelo francês Denis Villeneuve, a Terra é visitada por uma raça alienígena que aparentemente busca transmitir à espécie humana uma mensagem de importância vital. A linguista Louise Banks (Amy Adams) é então convocada para auxiliar na decifração da complexa linguagem dos extraterrestres, apelidados de heptapods, já que se assemelham a polvos dotados de sete tentáculos. Aos poucos, Louise consegue penetrar nos segredos dos misteriosos ideogramas dos heptapods, de uma complexidade assustadora para a mente humana. Ocorre que a linguagem dos extraterrestres expressa uma compreensão de tempo não-linear, já que a espécie é capaz de enxergar passado, presente e futuro em uma espécie de simultaneidade total. Ao familiarizar-se com essa linguagem, Louise se dá conta de que sua forma de interagir com o mundo está sendo radicalmente afetada, de modo que sua consciência temporal começa também a operar no registro alienígena. Esse fenômeno seria, portanto, uma comprovação da célebre tese de Sapir-Whorf (citada pela linguista a certa altura), segundo a qual a língua que falamos condiciona a maneira como pensamos e vemos o mundo. De fato, ao ter sua mente (suas conexões neuronais?) radicalmente reestruturada pela linguagem alienígena, Louise é capaz de enxergar o futuro e, deste modo, salvar a Terra de um destino trágico.

O filme de Villeneuve toca em pelo menos três complexos de questões que são caros aos leitores e estudiosos do filósofo tcheco-brasileiro Vilém Flusser: 1. o problema dos códigos e sua tradução intercultural; 2. o tema do alienígena e do estranhamento com as figuras da alteridade e 3. o imaginário do oceano ${ }^{2}$ e, mais particularmente, dos octópodes. Sabemos, como já demonstrou Rainer Guldin, que o problema da tradução atravessa toda a obra e pensamento de Vilém Flusser (2005). Não se trata apenas da questão da traduzibilidade linguística, mas do trânsito entre diferentes universos de referência. Flusser desenvolve continuamente a questão do como se movimentar entre diferentes culturas ou diferentes esferas culturais. Nesse sentido, até mesmo o trânsito entre as estruturas da razão e do imaginário consiste em um problema central para o pensador. Esse é, aliás, um problema persistente da ficção científica enquanto gênero. Ela existe num intervalo entre a imaginação ficcional e as afirmações rigorosas da ciência. Como traduzir um dado racional, científico para o domínio fluido e livre do imaginário, ou viceversa? Ou, melhor ainda, como fazer para habitar as "zonas cinzentas", os entrelugares situados nos interstícios entre domínios da realidade, do pensamento ou da linguagem?

2 Vale assinalar que os alienígenas parecem se mover em uma espécie de meio (médium) gasoso-aquoso, e que os caracteres de sua escrita são produzidos aparentemente por "jatos de tinta" emanados de seus tentáculos. 
Flusser nutria um interesse especial pela ficção científica. De fato, em um pequeno texto escrito em alemão e apresentado a um grupo informal em Viena (TV Club Wien), Flusser reflete sobre as relações entre esses dois campos - ciência e ficção -, defendendo a ideia de que muito da ciência contemporânea é de ordem tão ou mais imaginativa que a ficção ${ }^{3}$. É precisamente em uma zona cinzenta (graue Zone) singular em que esses domínios se encontram, algo expresso no aparentemente contraditório termo ficção científica. Para o filósofo, porém, é certo que hoje não há contradição entre esses dois termos. O que seria da ciência, afinal, sem a presença de ficções, sem hipóteses, sem experimentos mentais? O que seria da filosofia, poder-se-ia também perguntar, sem o mito e a alegoria, que ocuparam nos diálogos platônicos lugar de destaque? Mas Flusser vai ainda mais longe, e sugere mesmo que "a totalidade do edifício da ciência (wissenschaftliche Gebäude) é uma ficção" (FLUSSER, s/data: p. 1). Desse modo, a ciência seria apenas um caso especial de ficção. Isso porque, de acordo com a argumentação encadeada no texto, nenhuma das proposições científicas pode almejar ser inteiramente verdadeira. Para Flusser, uma frase como "chove" é tão desprovida de sentido (sinnlos) como o paradoxo "chove e não chove". A ciência seria absolutamente desinteressante se almejasse produzir apenas proposições desse tipo. Para Flusser, o conhecimento é uma função do interesse - ou talvez, se nos for permitido estender a argumentação, uma função do grau de maravilhamento. Para ele, proposições dotadas de sentido (sinnvolle) só podem ser mais ou menos prováveis, nunca inteiramente verdadeiras ou falsas. A verdade é um horizonte jamais inteiramente alcançável. A teoria do conhecimento que Flusser deseja professar é, desse modo, uma que peculiarmente se aproxima da verdade pelo seu oposto, o que podemos encontrar, segundo ele, na tradição talmúdica ou na escolástica. Poder-se-ia pensar, assim, uma "teoria do conhecimento, com certa capacidade imaginativa" (Vorstellungskraft) (FLUSSER, s/data, p. 2), cuja estratégia consistiria em atravessar por inteiro o ficcional para ali encontrar o não-ficcional. É isso, na verdade, que se deveria esperar da ficção científica: a produção de conhecimento via uma redução ao absurdo operando por meio da ficção ${ }^{4}$.

Não é exatamente isso que sugerem, em certo sentido, as extraordinárias "ficções filosóficas" ${ }^{\prime \prime}$ que Flusser empreendeu em muitos de seus textos? Pensemos naquela que é talvez a mais célebre delas, a fábula do Vampyroteuthis Infernalis (1987), cujo personagem central é precisamente um estranho octópode que se encontra nas antípodas do humano. Nesse curioso ensaio, misto de ficção e relato científico (que em alguns momentos lembra a impessoalidade dos relatos, "Berichte", de Kafka), Flusser lança mão da estranha criatura como espécie de alegoria para refletir, a partir das antípodas do homem,

3 Texto disponível online em < http://www.flusserstudies.net/node/552>. Acesso em 09/02/2017.

4 Não é meu objetivo aqui seguir nesta direção, e o espaço deste artigo não o permitiria, mas interessa observar que Flusser é, em vários aspectos, um seguidor do ficcionalismo como instrumento epistemológico, na linha de Kant e principalmente de Vaihinger, em sua Philosophie des als ob (1924). A esse respeito, ver o trabalho de Bouriau (2013).

5 Termo cunhado por seu amigo Abraham Moles. Cf. Moles (1990). 
sobre a condição humana e seus vínculos com a tecnologia. Na verdade, a curiosidade de Flusser com polvos, lulas e outras criaturas marinhas é bem mais antiga, e data pelo menos da elaboração de História do Diabo, publicado originalmente em 1965. Ao falar sobre a escala evolutiva do seres, Flusser especula:

Do ponto de vista dos pólipos gigantescos que habitaram os abismos dos oceanos são os cefalópodes o gênero mais "desenvolvido". O rio da vida tem o propósito de produzir os cefalópodes, e todos os gêneros "posteriores" (posteriores da nosso ponto de vista humano) não passam de degenerações no sentido exato desse termo (2010, p. 68).

Nesta discreta passagem, Flusser lança mão da ideia de ponto de vista (Standpunkt) como instrumento de relativização da perspectiva que tradicionalmente confere ao humano lugar central numa hierarquia ontológica. Entretanto, trata-se aqui de um exercício imaginativo passageiro, pois, em instâncias posteriores do texto, Flusser acaba por reafirmar a superioridade humana, meta final de toda a evolução. Há, possivelmente, porém, uma ponta de ironia nessa legitimação da supremacia humana (que é contestada claramente em vários outros momentos do pensamento do autor). Isso porque, segundo o autor, o critério último para determinar o domínio do homem como espécie é a luxúria. Somos o animal mais luxurioso de todos, e, portanto, o mais desenvolvido. Afinal, a reprodução da vida é a meta da existência, e nesse sentido nos encontraríamos no topo da escala evolutiva. Mas será mesmo? Em Vampyroteuthis Inferalis ${ }^{6}$, Flusser assinala continuamente o caráter "admirável e vertiginoso" da vida sexual do octópode (2011, p. 33). Citando Reich, ele sugere que os cefalópodes são criaturas que estão continuamente próximas da sexualidade e do "reino do amor na Terra" (2011, p. 56). Mais que isso, porém, Vampyroteuthis opera em uma lógica diversa, já que, diferentemente de nós, "brinca da morte e reprime o amor" (ibid.). Ainda assim, toda a existência de Vampyroteuthis, inclusive sua forma de perceber o mundo, é profundamente marcada pelo erotismo, insiste Flusser. Na "lula-vampiro do inferno" (tradução de seu nome científico em latim), encontramos um ser hipersexualizado, talvez o mais luxurioso de todos.

Esse longo fascínio de Flusser com os cefalópodes o torna, curiosamente, um autor extremamente atual. Em Vampyroteuthis Infernalis, o protagonista da fábula é pensado essencialmente como um alienígena, um estranhíssimo ser que faz lembrar a sugestão do autor expressa em outro texto não publicado, Seres de um outro mundo (Wesen aus einer anderen Welt). Ali, Flusser pergunta: por que razão deveríamos buscar alienígenas fora do nosso planeta quando há, aqui mesmo, tantas espécies "estranhas" ou "estrangeiras" (fremden Art) com as quais poderíamos tentar nos comunicar?

6 Neste artigo, farei uso de duas diferentes versões do texto, compostas pelo autor em alemão e português - e distinguidas nas referências pelos respectivos anos das publicações utilizadas (2002 e 2011). A versão original, em alemão, foi inicialmente publicada pela editora European Photography. Os manuscritos em português se encontravam preservados no Arquivo Flusser de Berlim e foram trazidos ao público somente em 2011 pela editora Annablume. 
[...] Mas a esperança de uma conversação com seres hipotéticos de outro mundo é supostamente menos fantástica. Não será isso uma prova da insanidade da humanidade contemporânea? Presumamos que esses seres de fato existam; que algo que pudesse ser definido como "vida" no mais amplo sentido se desenrolasse sobre Vênus, Marte ou um satélite de Júpiter. Algo assim seria para nós naturalmente desproporcionalmente estrangeiro, como um polvo gigante (Riesenpolyp) ou mesmo um pinheiro. Entrar em conversação com algo assim seria muito mais difícil do que com uma ameba ou com o patógeno do Tifo (apud FELINTO \& SANTAELLA, 2012, P. 181).

Sim, argumenta, Flusser: entrar em comunicação com um alienígena seria mais difícil que entabular uma conversação com uma outra espécie de nosso próprio planeta, já que compartilhamos da mesma história geológica e destino ontológico. O que nos faltaria para alcançar essas espécies seria, entre outras coisas, uma simpatia (Sympathie), a capacidade de assumir hipoteticamente o lugar do outro.

A ideia do octópode pensado como figura alienígena, em Flusser, é de uma ordem quase profética, dada a explosão recente do interesse científico pelos cefalópodes e o hoje recorrente tropo do caráter "extraterrestre" dessas criaturas. Em manchete de reportagem publicada em agosto de 2015, no The Mirror, lemos, por exemplo, que "o código genético do octópode é tão estranho que ele poderia ser alienígena, segundo cientistas" ${ }^{77}$. Em outra reportagem, publicado no mesmo ano no periódico Metro, encontramos chamada bastante parecida: "Octópodes 'são aliens', decidem cientistas após estudo de DNA"8. Isso porque eles possuem uma sequência genômica altamente complexa, com mais genes inclusive que os humanos. Essa complexidade parece se refletir em seu intrincado sistema nervoso e sua sofisticada inteligência. Desse modo, a escolha da forma cefalópode para representar os alienígenas no filme de Villeneuve não poderia ser mais acertada ${ }^{9}$. Mais curioso ainda é constatar que várias pesquisas recentes reforçam decisivamente a ideia, longamente explorada por Flusser, da riqueza e complexidade da vida sexual do Vampyroteuthis Infernalis. Diferentemente da maioria de seus outros parentes cefalópodes, que se acasalam somente no final de seus ciclos vitais, o Vampyroteuthis "consegue ficar assanhadinho (get frisky) com seus parceiros muitas e muitas vezes durante sua vida"10.

7 Disponível em <http://www.mirror.co.uk/news/technology-science/science/octopus-genetic-code-strangecould-6241463>. Acesso em 10/02/2017.

8 Disponível em <http://metro.co.uk/2015/08/12/octopuses-are-aliens-scientists-decide-after-dna-study-5339123/>. Acesso em 10/02/2017.

9 O tropo dos cefalópodes como alienígenas, bem como do diálogo com formas de inteligência não-terrenas, pode ser encontrado também em trabalhos acadêmicos recentes, como no estudo de Peter Godfrey-Smith, Other Minds: The Octopus, The Sea, and the Deep Origins of Consciouness: "se podemos fazer contato com cefalópodes como seres sencientes, não é porque compartilhamos uma história, não é por causa de parentesco, mas porque a evolução elaborou mentes duas vezes. Isso é provavelmente o mais perto que conseguiremos chegar de encontrar um alienígena inteligente" (2016, p. 9). Note-se aqui a semelhança com o argumento flusseriano de "Seres de um outro mundo".

10 Disponível em <https://www.theregister.co.uk/2015/04/21/vampire_squid_reproduction/>. Acesso em 10/02/2017. 
Na leitura de reportagens desse tipo, nas quais se busca seduzir o leitor pelo estranho e o maravilhoso, temos a impressão de que a ciência penetrou nos territórios da fantasia e da ficção científica. Razão e imaginação mostram-se, nesse campo, como irmãs. Para o documentarista francês Jean Painlevé (1902-1989), isso provavelmente não seria surpresa alguma. Fascinado pela vida marinha e fortemente influenciado pelo movimento surrealista, Painlevé produziu documentários de ciência natural marcados por uma beleza espectral e por um sentido de maravilhamento caracteristicamente barroco. Em Amours de la Pieuvre (1965), por exemplo, Painlevé filma um casal de octópodes engajados num ato sexual que dura horas e mesmo dias. Como definiu Ralph Rugoff, a estética dos trabalhos de Painlevé inspira "desconforto e maravilhamento" em proporções idênticas. Em seus filmes, é precisamente nosso "familiar conceito do humano que pode subitamente parecer alienígena ou mesmo suspeito, deixando-nos com um assombroso sentido de nossa própria estranheza" (2000, p. 50). Nada mais apropriado, pois, que o título dado pela Criterion à sua edição em DVD dos documentários de Painlevé: Science is Fiction (uma expressão do próprio Painlevé). Como escreveu Brigitte Berg, para Painlevé, "a ciência não poderia ser dissociada de valores humanos" (2000, p.5). Nesse aspecto, Flusser e o documentarista francês também se aproximam, já que, de acordo com o primeiro, o Iluminismo levou suas pretensões longe demais, para muito além do humano. Não só a ciência precisa ser humana, senão que também é necessário pensar um novo humanismo adequado aos nossos tempos. Um humanismo capaz de atuar contra o "barbarismo técnico" manifestado na forma de um racionalismo extremo (FLUSSER, 2002, p. 164).

Na verdade, o otimismo de Flusser quanto à realização dessas propostas se ancorava na emergência das novas tecnologias digitais. Para o pensador, a sociedade telemática trazia a promessa de novas ciências, novos imaginários e novas potências da criatividade. Não apenas as categorias da realidade e da ficção, senão também do tempo e do espaço, seriam reformuladas "por meio dos modelos de computação". Com isso, a "filosofia dos meios se torna uma 'teoria da tradução', uma reflexão e encenação dos processos de transformação das formas de escrita lineares em formas reticulares (netzartige)" (GROPP, 2006, ps. 257-258). Através de toda sua obra, portanto, mas mais especificamente no Vampyroteuthis Infernalis, Flusser buscou elaborar uma nova filosofia do humano capaz de realizar a difícil tarefa de combinar certos valores humanistas com perspectivas que hoje definiríamos como pós-humanas. Nesse sentido, o livro mais experimental de Flusser pode ser encarado como um pequeno tratado sobre a constituição de uma nova humanidade irremediavelmente alterada pelas condições tecnológicas da era computacional. Sua ficção filosófica seria uma forma de escrita situada entre ciência e arte que "ao mesmo tempo descreve, reflete e demonstra a fenomenalidade dos meios". A filosofia se transforma em "fenomenologia fantástica e, como tal, em teoria estética" (GROPP, 2006, p. 275). 


\section{Identidade e ponto de vista}

Entre as diversas problemáticas de que trata o ensaio de Flusser, destaca-se o tema da identidade - um tema que, aliás, foi explorado intensamente pela ficção científica (Cf. BUKATMAN, 1993). Vampyroteuthis é uma cornucópia de possibilidades identitárias, de escolhas que a humanidade da era cibernética pode empreender. Quando o filósofo fala sobre o abandono da "cápsula do eu", refere-se à fragmentação da fixidez que teria marcado o advento das construções identitárias até fins da modernidade. Abalado e explodido pelas telas, pela existência virtual, pelas modificações tecnológicas do corpo e da mente, o sujeito da sociedade telemática se encontra em uma encruzilhada fundamental. Face a essa situação, nunca antes a relação com o outro (agora estruturada em forma reticular) constituiu um problema tão cogente. Vampyrotuethis Infernalis é um exercício no perspectivismo, na construção de pontos de vista e de posições subjetivas. Não estamos, aqui, muito longe do perspectivismo ameríndio de Eduardo Viveiros de Castro, que envolve uma "multiplicidade perspectiva intrínseca ao real" (2015, p. 17), na qual "se nem todos os existentes são pessoas de facto, o ponto fundamental está em que nada impede (de jure) que qualquer espécie ou modo de ser o seja" (2015, p. 21). Trata-se, acima de tudo, da "possibilidade de ocupar um ponto de vista" (ibid.) - uma ideia que poderíamos definir, de fato, como profundamente flusseriana. Adotar um ponto de vista significa tomar uma posição, ocupar um lugar. Na era pós-fotográfica, pós-ideológica, não existiria mais um ponto de vista fundante, um lastro definido no qual uma verdade única poderia se ancorar. Defrontamo-nos agora com uma multiplicidade de pontos de vista, uma infindável gama de possibilidades, que torna o jogo identitário e ideológico complexo e interessante.

Toda vez que o fotógrafo esbarra contra um limite de determinada categoria
fotográfica, hesita, porque está descobrindo que há outros pontos de vista
disponíveis no programa. Está descobrindo a equivalência de todos os pontos
de vista programados, em relação à cena a ser produzida. É a descoberta do fato
de que toda situação está cercada de numerosos pontos de vista equivalentes.
E que todos esses pontos de vista são acessíveis (FLUSSER, 2002b, p.33, gr. nossos).

Se a ficção filosófica é um exercício imaginativo no qual se torna possível assumir outros pontos de vista, tomar o lugar de outros seres (inclusive não-humanos), faz todo o sentido que o pequeno ensaio filosófico de Peter Szendy, Kant chez les Extraterrestres, funde sua reflexão sobre o problema do ponto de vista em um conceito denominado de filosoficção. A coincidência com Flusser é surpreendente. Para Szendy, a obsessão de Kant com as figuras dos extraterrestres em sua antropologia filosófica constitui, por exemplo, um mecanismo "filosofictivo" visando pensar a singularidade da condição humana. O que o estudo de Szendy se propõe a fazer, portanto, é "extrair a necessidade de um certo 
por que não?, de uma dimensão filosofictiva à qual a filosofia não pode escapar, à qual ela deve se expor sempre que queira julgar e pensar o julgamento. Ou melhor, tão logo ela é confrontada com um ponto de vista" (2011, p.71, gr. do autor). É o que Szendy define, em última instância, como a "filosoficção do inteiramente outro" (philosophiction du tout-autre), um confronto com a experiência radical da alteridade, da entidade alienígena, através do qual ensaiamos o estabelecimento de nossa própria identidade.

Desse modo, talvez se pudesse afirmar que Vampyroteuthis Infernalis representa o mais perfeito "alienígena" imaginável - um extraterrestre em nossa própria terra; o espelho da alteridade radical no qual nos enxergamos. Além disso, os oceanos nos quais habita a criatura sempre constituíram um reservatório de mitos e lendas fundamentais para nosso imaginário. Mais ainda: como afirma Gunter Scholtz em seu belo Philosophie des Meeres, o mar foi o berço da filosofia assim como seu princípio fundamental (2016, p. 13). Filosofia e poesia encontram, afirma Scholtz, morada nos oceanos. Vampyroteuthis habita nas profundezas abissais. É uma criatura das trevas, é uma entidade que sempre se subtrai a nossas tentativas de aprisioná-lo. Como afirma Flusser, ele escapa continuamente tanto das nossas redes de pesca como de nossas redes epistemológicas (2011, p. 23). Essa permanente condição de estranheza, de distanciamento, é um dos elementos que nos seduz no Vampyroteuthis. Ele é o outro, o inteiramente outro - e, dessa forma, paradoxalmente, próximo de nós. Se continuamos a tecer a rede de analogias com que este texto se inicia, é relevante lembrar que Arrival trata, fundamentalmente, do problema da comunicação e da traduzibilidade. Os extraterrestres chegam em um planeta dividido por linguagens e ideologias. É precisamente a sua linguagem alienígena, estranha, exótica, inteiramente outra, que permitirá a essa humanidade à beira de uma guerra global superar o fosso babélico e alcançar a paz. O horizonte do imaginário bíblico não está distante, já que a maior dádiva concedida por Deus aos homens é a linguagem, e mesmo o mestre da criação usa da palavra para moldar o universo ("e Deus disse..."). E é no episódio babélico, mais tarde, que a dádiva da compreensão mútua será desintegrada pela multiplicação das línguas. Mas nossas linguagens são temporalmente limitadas, lineares, desenrolando-se sequencialmente no tempo. A língua dos octópodes alienígenas é simultaneidade, instantaneidade que transforma radicalmente a subjetividade de Louise. Em um movimento de empatia ideal, Louise se torna também "alienígena", empreende um encontro transformador com o outro e reconstrói radicalmente sua identidade. Mas tudo isso ao mesmo tempo em que, paradoxalmente, se descobre mais humana do que jamais fora antes. No interior dessa experiência, ela encontra uma nova dimensão de humanidade: seu enamoramento e sua gravidez são os símbolos evidentes dessa humanização da solitária cientista. De certo modo, não seria o nascimento dessa criança o símbolo da nova raça humana transformada pelo contato com o inteiramente outro? A trama de Arrival se organiza, portanto, nos polos do conflito entre as diferenças humanas e as diferenças extraterrestres. A "ferramenta" dos heptapods - termo que Louis irá adotar 
mais tarde para o que antes parecia ser a palavra "arma" no vocabulário alienígena afastará a possibilidade iminente de uma guerra mundial.

\section{Diferença, conflito e a anomia dos mares}

As ideias de conflito e paz perpétua são também aspectos centrais do trabalho de Szendi acima mencionado. Na primeira parte de seu livro, o filósofo trata do tema da cosmopolítica a partir da obra de Carl Schmitt. A ciência política e jurídica de Schmitt se funda sobre a noção de apropriação da terra. Não há movimento sem que exista um espaço livre, e a história da humanidade é a história da apropriação do espaço - o nomos da terra. Mas se toda a terra já foi em nossos dias apropriada e partilhada, para onde poderemos nos mover? Para os mares ou mesmo para o espaço sideral, imagina Schmitt. O mar é, diferentemente da terra, um elemento que não conhece unidade real entre espaço e direito, entre ordem e localização. E o mar é livre porque não permite deixar rastros (Spuren)11. Se as guerras são essencialmente disputas por espaços (territoriais ou ideológicos), contra quem iríamos guerrear se a humanidade considerasse a Terra como um espaço inteiriço e unificado? É assim que devemos entender a enigmática ideia que aparece tantas vezes na obra de Schmitt: "a humanidade enquanto tal não pode fazer guerra, pois ela não tem inimigo, ao menos sobre este planeta" (SZENDY, 2011, p.50). Nosso inimigo global teria de ser, portanto, o alienígena - como, aliás, a ficção científica imaginou tantas e tantas vezes. A possibilidade da política, para Schmitt, reside nessa relação entre amigo e inimigo - ou seja, numa estrutura relacional. O alienígena, esse amigo-inimigo do nosso imaginário midiático, se traduz, pois, em uma relação. Em Arrival, são eles precisamente que evitam a guerra ao trazer aos humanos o que inicialmente se supõe ser uma arma. Ironia suprema: eles nos oferecem um novo "espaço" para nos movimentarmos, o espaço de um tempo que, não sendo mais linear, nos permite ir em todas as "direções", andar para a frente e para trás sem impedimentos.

O mar, o tempo e o cosmos como fronteiras finais: espaços que não deixam rastros e não permitem a fixação identitária. Não por coincidência, Schmitt caracteriza o homem como ser terrestre (Landwesen), tendendo continuamente a desqualificar aqueles que estão próximos do mar. Isso porque "no mar aberto não existem limites, fronteiras, locais consagrados, orientações sacras, nem lei nem propriedade" (2006, p. 43). O mar é, assim, o local onde tudo é possível, e, por isso, talvez faça sentido ligar o fascínio marítimo à Bondelosigkeit de Flusser, ou seja, sua filosofia da "falta de fundamento". Professando uma identidade maleável e sempre em movimento, o pensador se via como indivíduo permanentemente desterrado, vagando entre línguas e culturas sem nunca encontrar um porto seguro. Nesse estado, a distinção entre verdadeiro e falso soçobra por completo.

11 Bernhard Siegert escreverá, em seu fascinante Passage des Digitalen, que "do espaço elementar do mar derivou o espaço elementar do digital e dos meios" (Aus den Elementarraum des Meeres ist der Elementarraum des

Digitalen und der Medien geworden) (2003, p. 19) 
Em certa medida, essa é também a condição existencial de nossa era. Há homens, contudo, para os quais essa experiência é particularmente sensível. Essa é a própria ambiência (Stimmung) na qual habitam eles, seres que perderam todo o chão debaixo dos pés (jeden Boden unter den Fußen verloren haben) (FLUSSER, 1992, p. 11). A biografia de Flusser constitui, assim, um laboratório para a investigação do estado de Bodenlosigkeit. Os homens e as criaturas do mar são seres inevitavelmente marcados pela ausência de fundamento. É precisamente por isso que constituem, na filosofia política de Carl Schmitt, figuras suspeitas. Os terríveis Fischmenschen ("homens-peixe") são seres estranhos, perigosos, para os quais nossas (dos homens da terra) representações de espaço e de tempo seriam "estranhas e incompreensíveis (fremd und unverständlich)" (SCHMITT, 2008, p. 10). O ideal da pureza identitária e racial, elemento subreptício no pensamento de Schmitt (que foi colaborador do regime nazista), escandaliza-se face à anomia dos mares e seus seres alienígenas. Os homens-peixe são uma encarnação da potência selvagem do hibridismo, esse território das misturas onde a lei e o fundamento sólido perdem sentido.

Todo híbrido, criatura das fronteiras ou da confusão das fronteiras, como o ciborgue de Haraway (2009), perturba toda ordem taxonômica possível, destitui a empresa identitária e qualquer gesto de fixação no espaço. De fato, como nota Eugene Thacker, nossas tentativas de sistematizar e ordenar cientificamente a natureza não contribuíram para que nos sentíssemos mais à vontade no mundo. Pelo contrário, fizeram apenas com que percebêssemos mais claramente que "somos nós os alienígenas" (2015, p. 74). Evocando a fábula flusseriana do Vampyroteuthis, Thacker nota que a maior intuição do filósofo foi perceber nossa incapacidade de apreciar ou nos relacionarmos com aquilo que é da ordem do inumano. O sentido de repulsa expresso numa curiosa passagem de Vampyroteuthis Infernalis é aproximado por Thacker de uma história de H.P. Lovecraft, o escritor norteamericano obcecado por estranhos seres marinhos e pelo terror do diferente e do híbrido. Em Dagon, Lovecraft narra a odisseia de um náufrago aportando em uma misteriosa ilha perdida no meio do oceano. Coberta de podridão, com carcaças de peixes e outros seres marinhos espalhados por sua superfície, a ilha exala um sentimento de horror cósmico que atravessa toda a narrativa. Levado à beira da loucura por suas estranhas visões, o protagonista da história é marcado por uma "repulsa antropológica que não irá abandoná-lo, e a única coisa que o enoja mais que as criaturas em forma de polvo (cephalopod-like creatures) das profundezas é sua própria espécie, incapaz de compreender um mundo ao mesmo tempo alienígena e indiferente à perspectiva humana" (2015, p. 75).

Em muitos sentidos, o diálogo com o alienígena que Flusser encena em Vampyroteuthis Infernalis é um diálogo com aqueles aspectos ou restos não-humanos que sobreviveram escondidos no interior do próprio homem. As tentativas de expulsar toda medida de animalidade do homem, de nos constituir a partir dessa diferença específica que separa o humano da natureza criaram uma ilusão de pureza que agora se desfaz no confronto com o tema do pós-humanismo. O que se faz necessário hoje é explorar 
essas dimensões não-humanas, esses abismos nos quais se deve abandonar todo privilégio antropocêntrico e toda pretensão de hierarquia ontológica. No pensamento de Flusser, como já foi sugerido, o mar funciona como um símbolo dessas dimensões, como medium epistemológico para o desenvolvimento de uma reflexão não mais condicionada pelo bios terrestre da filosofia e da teoria crítica (JUE, 2014, p. 85). Não é mera coincidência o fato de os discursos da cibercultura abusarem das metáforas marinhas. "Navegamos" em um "oceano de dados"; somos os "timoneiros" (é esse o sentido original de kybernetes) do futuro; vivemos em uma cultura "líquida"; os que copiam ilegalmente arquivos de dados na internet são "piratas"... A essas metáforas, poderíamos acrescentar a divertida imagem flusseriana do polvo como Weichtier, como "criatura mole" que emblematiza o software (2002, p. 63). Tais metáforas são de todo adequadas se considerarmos uma arqueologia profunda da cultura computacional. Para Bernhard Siegert, que traça arqueologicamente as origens do paradigma digital em técnicas de escrita (contabilidade, livros de registro) desenvolvidas desde o alvorecer da modernidade,

a figura do notário da embarcação (Bordschreiber), do representante do rei no mar que, em fundamento instável, marca posição solitária contra a desterritorialização do direito, da economia e do sujeito na profundeza sem solo (bodenlosen) do oceano, poderia constituir a figura emblemática do analítico (2003, p. 18).

Pois em Siegert, precisamente, a oposição entre os paradigmas analógico e digital, entre o analítico e aquilo que não permite análise, é traduzida na oposição entre terra firme e mar. Se o mar é o elemento típico de uma escrita sem pai e afastada do logos, o discurso vivente se finca, por outro lado, na terra. O logos é um homem terrestre (ein Landmann). Desse modo, o mar é o outro do nomos e da polis, bem como da lógica e gramática sobre elas assentadas. É por isso que a escrita não nasce na polis temerosa da água, mas nas "sociedades hidráulicas do Oriente" (2003, p. 56) - e nasce como forma matemática de registro e contabilidade ${ }^{12}$. Siegert aborda, pois, as práticas de escrita (Zeichenpraktiken) que marcaram o desenvolvimento das ciências e da tecnologia no Ocidente. Não se trata aqui, evidentemente, do sentido linguístico do termo, mas de uma graphé (no modo derridiano) para além ou aquém da linguagem, fundada em listas, tabelas, coordenadas, sistemas de notação matemática. Lançando mão do conceito kittleriano de Aufschreibesysteme ("sistemas de notação") ${ }^{13}$, Siegert identifica no fundamento de nossos saberes modernos uma prática de inscrição que irá sofrer ruptura fundamental a partir de meados do século XVIII. Essa ruptura é precisamente o que permitirá o surgimento dos meios técnicos, fundados numa noção de irrepresentabilidade. Se antes a totalidade do mundo era representável em signos, numa continuidade inabalável do real, após a ruptura $(R i ß)$ ingressamos num mundo não mais analisável, não mais totalizável.

12 Uma concepção baseada nos trabalhos da arqueóloga Denise Schmandt-Besserat com os antigos tokens sumérios. Cf. Schmandt-Besserat, 1996.

13 Cf. Kittler, 2003. 
Agora entra em cena uma descontinuidade radical (expressa, mais tarde, nos zeros e uns, nos bits e bytes, da cultura digital) que desterritorializa os domínios da análise. É nesse sentido que os textos platônicos são atravessados por uma profunda desconfiança da água e do mar; "pois a água é o medium das misturas; na água se encontram facilmente as oposições" (SIEGERT, 2003, p. 36).

\section{Conclusão: o Outro está onde não há solo}

Para Flusser, por sua vez, o homem encontra seu destino histórico-tecnológico na criatura das profundezas marinhas e nos abismos aquáticos em que habita. Assim escreve o pensador na versão alemã do texto: "como animais que ultrapassaram sua animalidade (ou pensam que devem ultrapassá-la), nós devemos nos engajar na busca da imortalidade através do outro, como faz o Vampyroteuthis" (2002, p. 650). Esse engajamento significa a entrega radical ao universo das novas tecnologias eletrônicas, na complexa dialética entre materialidade e imaterialidade que caracteriza a experiência do universo digital. As tecnologias "vampyrotêuthicas" - suas emissões bioluminescentes e jatos de tinta -, nascidas nas profundezas do oceano, encontram seu paralelo em nossos aparatos tecnológicos. É certo que

o mundo do qual emerge o Vampyroteuthis exige outras categorias ontológicas diferentes das nossas: aquelas da paixão da noite, não as da luminosidade do dia. Não é a razão desperta que o mundo vampiromórfico exige, mas o sonho (2002, p. 42).

Entretanto, nem por isso devemos considerar uma distância radical entre nós, uma relação de incomunicação e desencontro do homem com Vampyroteuthis. Afinal,

como seres equivocados complexos e dotados de cérebros complexos, somos ambos ao mesmo tempo racionais e sonhadores. Mas nossos planos de consciência estão estruturados de forma invertida. O que para nós é consciência desperta, é para ele o inconsciente (ibid.).

O homem da era digital se aproxima progressivamente do Vampyroteuthis. Seu oceano tecnológico, segundo crê Flusser, talvez com excessivo otimismo, será um playground onde o trabalho manual dará lugar aos jogos criativos com as tecnologias e à empresa da contínua criação de novos mundos virtuais. E escrever o futuro, para essa humanidade transformada, significará "escrever na água, mover-se na ausência do nomos" (SIEGERT, 2003, p. 36), ou seja, abandonar todo solo fixo para se aventurar em territórios não mapeados, no universo da novidade radical.

Em Arrival, vale a pena lembrar, a escrita alienígena é produzida com jatos líquidovaporosos emitidos pelos tentáculos alienígenas. Uma escrita que se dissolve logo após 
ser produzida, que não se inscreve em superfície firme e existe apenas em forma instável. Uma escrita, precisamente, que rompe a ordem do simbólico, que destrói a linearidade alfabética, que institui uma multiplicidade temporal perturbadora. E talvez encontremos, aqui, o maior equívoco do filme em termos de uma possível "tradução" flusseriana. Isso porque, na decifração desses signos múltiplos, Louise encontra os elementos para conseguir a unificação de uma humanidade fragmentada. Todavia, no imaginário marítimo-aquático de Flusser a questão não é a de uma unidade humana harmoniosa efetivada em moldes tipicamente hollywoodianos. Trata-se, ali, sempre e de novo, de um encontro com o outro, com a diferença, no qual nenhum dos elementos em relação é absorvido ou solucionado numa síntese. O que encontramos no autor de Vampyroteuthis Infernalis é uma espécie de técnica de confronto com o "inteiramente outro", um exercício imaginativo visando possibilitar a momentânea assunção desse lugar da alteridade, uma posição sempre movente e instável. Esse local é o oceano, real e simbólico, no qual, precisamente, se produz a experiência do filosofar. "A vivência (Stimmung) da filosofia repousa, antes de tudo, na relação com o mar" (JASPERS apud SCHOLTZ, 2016, p. 181). Ali não nos é oferecido "nada de permanente, nenhum solo (Boden) - e, porém, ela não nos deixa afundar na ausência de fundamento (Bodenlosen), mas sim dá testemunho do fundamento de todas as coisas" (ibid.). Sair do território da nossa familiaridade para investigar o mistério do outro é a tarefa mais bela da filosofia. E também, arrisquemos dizer, da comunicação.

Erick Felinto é professor do Departamento de Teoria da Comunicação da UERJ e Pesquisador do CNPq.

erickfelinto@gmail.com

\section{Referências}

BELLOWS, A. M.; MCDOUGALL, M.; BERG, B. (eds.). Science is Fiction: The Films of Jean Painlevé. Cambridge: The MIT Press, 2010.

BERG. "Jean Painlevé, 1902-1989", em BELLOWS, A. M.; MCDOUGALL, M; BERG, B. (eds.). Science is Fiction: The Films of Jean Painlevé. Cambridge: The MIT Press, 2010.

BOURIAU, C. Le “Comme Si": Kant, Vaihinger et le Fictionalisme. Paris: Éditions du Cerf, 2013.

BUKATMAN, S. Terminal Identity: The Virtual Subject in Postmodern Science Fiction. Durham: Duke University Press, 1993.

CALABRESE, O. A Idade Neobarroca. Lisboa: Edições 70, 1999.

FELINTO, E. \& SANTAELLA, L. O Explorador de Abismos: Vilém Flusser e o Pós-Humanismo. São Paulo: Paulus, 2012.

FLUSSER, V. Bodenlos: Eine Philosophische Autobiographie. Düsseldorf: Bollman, 1992. 
\& BEC, Louis. Vampyrotheutis Infernalis: eine Abhandlung samt Befund des Institut Scientifique de Recherche Paranaturaliste. Göttingen: Hubert \& Co., 2002.

Filosofia da Caixa Preta: Ensaios para uma Futura Filosofia da Fotografia. Rio de Janeiro: Relume-Dumará, 2002.

A História do Diabo. São Paulo: Annablume, 2010.

Vampyroteuthis Infernalis. New York: Atropos Press, 2011.

GODFREY-SMITH, P. Other Minds: the Octopus, the Sea, and the Deep Origins of Consciousness. New York: Farrar, Strauss and Giroux, 2016.

GROPP, P. Szenen der Schrift: Medienästhetische Reflexionen in der Literarischen Avantgarde nach 1945. Bielefeld: Transcript, 2006.

GULDIN, R. Philosophieren zwischen Sprachen: Vilém Flussers Werk. München: Wilhelm Fink, 2005.

GUZZONI, U. Wasser: Das Meer und die Brunnen, die Flüsse und der Regen. München: Karl Alber Freiburg, 2015.

HARAWAY, D. et al. Antropologia do Ciborgue: as Vertigens do Pós-Humano. Belo Horizonte: Autêntica, 2009.

JUE, M. "Vampyre Squid Media", em Grey Room n. 57. Massachussets: MIT Press, 2014.

KITTLER, F. Aufschreibesysteme 1800/1900. Berlin: Fink, 2003.

LOVECRAFT, H. P. Dagon. São Paulo: Iluminuras, 2005.

MOLES, A. "Philosophiefiktion bei Vilém Flusser", em RAPSCH, V. (org.). Überflusser: Die Fest-Schrift zum 70. von Vilém Flusser. Düsseldorf: Bollman, 1990

MUNSTER, A. Materializing New Media: Embodiment in Information Aesthetics. Dartmouth: Dartmouth College Press, 2006.

RUGOFF, R. "Fluid Mechanics", em BellOWS, A. M; MCDOUGALL, M; BERG, B (eds.). Science is Fiction: The Films of Jean Painlevé. Cambridge: The MIT Press, 2010.

SCHMANDT-BESSERAT, D. How Writing came About. Austin: University of Texas Press, 1996.

SCHMITT, C. The Nomos of the Earth. New York: Telos Press, 2006.

. Land und Meer: eine weltgeschichtliche Betrachtung. Stuttgart: Klett-Cotta, 2008.

SCHOLZ, G. Philosophie des Meeres. Hamburg: Mare, 2016.

SZENDY, P. Kant chez les Extraterrestres: Philosophictions Cosmopolitiques. Paris: Éditions de Minuit, 2011.

THACKER, E. Tentacles longer than Night (Horror of Philosophy vol. 3). Winchester: Zero Books, 2015. VIVEIROS DE CASTRO, E. Metafísicas Canibais. São Paulo: Cosac Naify, 2015. 